\title{
PENGARUH KUALITAS LAYANAN TERHADAP LOYALITAS GURU DENGAN KEPUASAN KERJA SEBAGAI VARIABEL INTERVENING DI SEKOLAH ISLAM TERPADU (SIT)
}

\author{
Salman Farisi ${ }^{1,}$ Hulmansyah $^{2}$, Nurul Huda ${ }^{3}$
}

s farisi010@yahoo.com

Program Magister Manajemen Sekolah Pascasarjana Universitas YARSI

Received: 15 September 2018

Final Acepted: 31 Oktober 2018

Published Online: Desember 2018

Keywords:

Service quality, job satisfaction, loyalty, integrated Islamic school, teacher.

Corresponding Authors:

* Salman Farisi

\begin{abstract}
This study is to determine the effect of service quality and job satisfaction on the loyalty of teachers and employees in the Integrated Islamic School, using path analysis test using pathPLS 3.0, which is a causal step (path of coefficient) strategy, this model aims to determine the direct and indirect set of independent variables (exogenous) to the dependent variable (endogenous), path keofisien value or the magnitude of the relationship or the effect of latent constructs carried out by the Bootrapping procedure measurement results show significant results this means that service quality variables are able to strengthen the variable job satisfaction and loyalty variables. Respondents in this study were teachers and employees of the Integrated Islamic School in the Banyuwangi Regency area, which amounted to 145 samples using non probability sampling techniques with a purposive sampling approach. The results showed that service quality has a significant direct effect as well as through job satisfaction as a mediator of loyalty. It is known that the indirect effect of the job satisfaction variable as mediator on loyalty variables is stronger than the direct effect of the service quality variable on the loyalty variable.
\end{abstract}

Copyright JEBA 2018., All rights reserved

\begin{abstract}
ABSTRAK
Penelitian ini untuk mengetahui pengaruh kualitas pelayanan dan kepuasan kerja terhadap loyalitas guru dan karyawan di Sekolah Islam Terpadu, menggunakan uji analisis jalur (path analysis) menggunakan SmartPLS 3.0 yaitu dengan strategi causal step (path of coefficient), model ini bertujuan untuk mengetahui pengaruh langsung maupun tidak langsung seperangkat variabel bebas (eksogen) terhadap variabel terikat (endogen), nilai keofisien jalur atau besarnya hubungan atau pengaruh konstruk laten dilakukan dengan prosedur Bootrapping hasil pengukuran menunjukkan hasil yang signifikan hal ini berarti variabel kualitas layanan mampu memperkuat variabel kepuasan kerja dan variabel loyalitas. Responden dalam penelitian ini adalah guru dan karyawan Sekolah Islam Terpadu di wilayah Kabupaten Banyuwangi yang berjumlah 145 sampel dengan menggunakan teknik pengambilan sampel non probability sampling dengan pendekatan purposive sampling. Hasil penelitian menunjukkan bahwa kualitas layanan berpengaruh signifikan secara langsung maupun melalui kepuasan kerja sebagai pemediasi terhadap loyalitas. Diketahui bahwa pengaruh tidak langsung dari variabel kepuasan kerja sebagai
\end{abstract}


pemediasi terhadap variabel loyalitas lebih kuat dibandingkan pengaruh langsung dari variabel kualitas layanan terhadap variabel loyalitas.

\section{PENDAHULUAN}

Sekolah Islam Terpadu (SIT) pada hakikatnya adalah sekolah yang mengimplementasikan konsep pendidikan Islam berlandaskan Al-Quran dan As-Sunnah. Konsep operasional SIT merupakan akumulasi dari proses pembudayaan, pewarisan dan pengembangan ajaran agama Islam, budaya dan peradaban Islam dari generasi ke generasi. Sekolah Islam Terpadu adalah sekolah yang bertekad keras untuk menjadikan nilai dan ajaran Islam terjabarkan dalam seluruh aspek yang terkait dengan penyelenggaraan sekolah.

Standar pendidik (guru) dan tenaga kependidikan Sekolah Islam Terpadu mengacu pada Peraturan Pemerintah No. 19 Tahun 2005 tentang Standar Nasional Pendidikan. Selain itu juga, Standar ini mengacu pada Permendiknas No. 13 Tahun 2007 tentang Standar Kepala Sekolah dan Peremendiknas No. 16 Tahun 2007 tentang Standar Kualifikasi Akademik dan Kompetensi Guru (Standar Mutu Kekhasan Sekolah Islam Terpadu, 2014).

Keberhasilan suatu jasa pelayanan dalam mencapai tujuannya sangat tergantung pada konsumennya, dalam arti sekolah memberikan layanan yang bermutu kepada para pelanggannya (guru) akan sukses dalam mencapai tujuannya. Sekarang ini mutu pelayanan telah menjadi perhatian utama dalam memenangkan persaingan. Mutu pelayanan dapat dijadikan sebagai salah satu strategi sekolah untuk menciptakan kepuasan konsumen. Suatu pendidikan bermutu tergantung pada tujuan dan yang akan dilakukan dalam pendidikan. Definisi pendidikan bermutu harus mengakui bahwa pendidikan apapun termasuk dalam suatu sistem. Mutu dalam beberapa bagian dari sistem mungkin baik, tetapi mutu kurang baik yang ada di bagian lain dari sistem, yang menyebabkan berkurangnya mutu pendidikan secara keseluruhan dari pendidikan.

Model kualitas pelayanan yang dikembangkan oleh Zeithaml adalah bukti langsung (reliability), ketanggapan (responsiveness), jaminan (assurance), dan empati (emphaty) (Tjiptono, 2012). Apabila jasa pelayanan yang diterima atau dirasakan sesuai dengan yang diharapkan maka mutu pelayanan yang dipersepsikan baik dan memuaskan. Jika pelayanan 
jasa yang diterima melampaui harapan pelanggan maka mutu pelayanan dipersepsikan sebagai mutu yang ideal. Sebaliknya jika pelayanan yang diterima lebih rendah daripada yang diharapkan, maka mutu pelayanan dipersepsikan buruk.

Kepuasan kerja merupakan sasaran penting dalam manajemen Sumber Daya Manusia (SDM), karena secara langsung maupun tidak langsung akan berpengaruh terhadap produktifitas kerja. Kepuasan kerja adalah cara individu merasakan pekerjaan yang dihasilkan dari sikap individu tersebut terhadap berbagai pekerjaannya.

Loyalitas merupakan tekad dan kesanggupan individu untuk mentaati, melaksanakan. Mengamalkan peraturan - peraturan dengan penuh kesadaran dan sikap tanggung jawab. Hal ini dibuktikan dengan sikap dan tingkah laku kerja yang positif. Loyalitas tumbuh dari diri karyawan itu sendiri, hal tersebut berasal dari kesadaran bahwa antara karyawan dengan perusahaan merupakan dua pihak yang saling membutuhkan, karyawan membutuhkan perusahaan sebagai tempat mencari penghidupan dan kebutuhan dalam kegiatan sosial, sedangkan perusahaan juga mempunyai kepentingan pada karyawan, khususnya karyawan yang memiliki kontribusi yang besar terhadap perusahaan.

Kabupaten Banyuwangi merupakan kabupaten terluas di provinsi Jawa Timur, dengan standar gaji UMR Berdasarkan Peraturan Gubernur Jawa Timur Nomor 121 Tahun 2016 Tentang Upah Minimum Kabupaten/Kota Di Jawa Timur Tahun 2017 Rp. 1.730.917,50 dan merupakan daerah yang masih dominan agribisnis dengan sub sektor tanaman bahan makanan dan sub sektor perikanan laut.

Sekolah Islam Terpadu yang tergabung di Jaringan Sekolah Islam Terpadu (JSIT) yang ada di Kabupaten Banyuwangi Provinsi Jawa Timur belum memiliki upah yang sesuai standar UMR yang sesuai dengan Peraturan Gubernur Jawa Timur Tahun 2017.

Kabupaten Banyuwangi merupakan kabupaten terluas di provinsi Jawa Timur (5782,40 km²), dengan standar gaji UMR Rp. 1.730.917,50, dan Sekolah Islam Terpadu di Kabupaten Banyuwangi masih dibawah standar UMR, idelanya dengan upah dibawah standar maka loyalitas akan berkurang, namun fakta di sekolah Islam Terpadu dengan upah yang masih di bawah standar loyalitas tidak berkurang.

Berdasarkan latar belakang diatas loyalitas dari seorang guru (pendidik) sangat diperlukan, loyalitas yang baik akan memberikan dampak yang baik terhadap peserta didik (siswa) maupun sekolah, dengan demikian tujuan penelitian ini 
1. Mengetahui dan menganalisis pengaruh kualitas pelayanan terhadap loyalitas guru di Sekolah Islam Terpadu.

2. Mengetahui dan menganalisis pengaruh kepuasan kerja guru terhadap loyalitas guru di Sekolah Islam Terpadu.

3. Mengetahui dan menganalisis pengaruh kualitas pelayanan dan kepuasan kerja guru terhadap loyalitas guru Sekolah Islam Terpadu.

\section{KAJIAN TEORI}

\section{Kualitas Pelayanan}

Tjiptono (2014) menyatakan kualitas pelayanan berfokus pada upaya pemenuhan kebutuhan dan keinginan konsumen serta ketepatan penyampaianya untuk mengimbangi harapan konsumen.

Menurut Parasuraman, Zeithaml, dan Berry (1995) yang dikutip oleh Tjiptono (2012) terdapat lima dimensi pokok untuk mengukur kualitas layanan. Dimensi pokok tersebut antara lain:

1) Realibilitas (Realibility), berkaitan dengan kemampuan perusahaan memberikan layanan yang disajikan secara akurat dan memuaskan.

2) Daya Tanggap (Responsiveness), berkenaan dengan kesediaan dan kemampuan penyedia layanan untuk membantu para pelanggan dan merespon permintaan mereka dengan segera.

3) Jaminan (Assurance), berkenaan dengan pengetahuan dan kesopanan karyawan serta kemampuan mereka dalam menumbuhkan rasa percaya (trust) dan keyakinan pelanggan (confidence).

4) Empati (Empathy), berarti bahwa perusahaan memahami masalah para pelanggannya dan bertindak demi kepentingan pelanggan, serta memberikan perhatian personal dan pemahaman atas kebutuhan individual para pelanggan tersebut.

5) Bukti Fisik (Tangibles), berkenaan dengan penampilan fisik fasilitas layanan, peralatan/ perlengkapan, sumber daya manusia, dan materi komunikasi perusahaan.

Parasuraman, Zeithaml, dan Berry (1988) dalam Tjiptono dan Chandra (2007), mengemukakan lima dimensi kualitas pelayanan berikut ini : 
1) Reliability (Reliabilitas)

Berkaitan dengan kemampuan instansi untuk memberikan pelayanan yang akurat sejak pertama kali tanpa membuat kesalahan apapun dan menyampaikan pelayanannya sesuai dengan waktu yang disepakati.

Indikatornya terdiri dari :

1. Konsistensi kinerja (performance), Petugas mampu menyampaikan pelayanan secara benar sejak awal (right the first time).

2. Sifat dapat dipercaya (dependability), Petugas mampu memenuhi janjinya secara akurat dan andal, misalnya memberikan pelayanan sesuai dengan jadwal yang disepakati dan menyimpan data secara tepat.

2) Responsiveness (Daya Tanggap)

Berkenaan dengan kesediaan dan kesiapan para petugas untuk membantu para penerima layanan dan memberikan pelayanan secara cepat. Indikatornya terdiri dari :

1. Kesediaan dan kesiapan petugas, Petugas bersedia dan memiliki kesiapan untuk membantu para penerima layanan dan merespons permintaan mereka.

2. Kecepatan petugas, Petugas selalu menginformasikan kapan pelayanan akan diberikan dan kemudian memberikan pelayanan secara cepat.

3) Assurance (Jaminan)

Perilaku para petugas yang mampu menumbuhkan kepercayaan para penerima layanan terhadap instansi dan instansi dapat menciptakan rasa aman bagi para penerima layanan. Jaminan juga berarti bahwa para petugas selalu bersikap sopan dan menguasai pengetahuan dan keterampilan yang dibutuhkan untuk menangani setiap pertanyaan atau masalah para penerima layanan. Indikatornya terdiri dari :

1. Kompetensi petugas, Petugas menguasai keterampilan dan pengetahuan yang dibutuhkan agar dapat memberikan pelayanan sesuai dengan kebutuhan penerima layanan.

2. Kesopanan petugas, Petugas yang berhubungan langsung dengan penerima layanan bersikap sopan dan ramah.

3. Kredibilitas petugas, Petugas memiliki sifat jujur dan dapat dipercaya, yaitu mencakup citra instansi, karakter pribadi petugas dan interaksi dengan penerima layanan. 
4. Keamanan, Petugas dapat menumbuhkan perasaan bebas dari bahaya, risiko, atau keragu-raguan kepada para penerima layanan. Termasuk di dalamnya adalah keamanan fisik, keamanan finansial, dan kerahasiaan.

4) Empathy (Empati)

Petugas memahami masalah para penerima layanan dan bertindak demi kepentingan penerima layanan, serta memberikan perhatian personal kepada para penerima layanan dan memiliki jam operasi yang nyaman.

Indikatornya terdiri dari:

1. Akses petugas, Penerima layanan memperoleh kemudahan untuk menghubungi atau menemui petugas. Hal ini berarti lokasi instansi mudah dijangkau, waktu mengantri atau menunggu tidak terlalu lama, dan saluran komunikasi instansi mudah dihubungi (contohnya telepon, surat, email, fax, dan seterusnya).

2. Komunikasi petugas, Petugas mampu menyampaikan informasi kepada penerima layanan dalam bahasa yang mudah dipahami, serta selalu mendengarkan saran dan keluhan penerima layanan.

3. Kemampuan memahami penerima layanan, Petugas berupaya memahami penerima layanan dan kebutuhan spesifik mereka dan memberikan perhatian individual.

5) Tangibles (Bukti Fisik)

Berkenaan dengan daya tarik fasilitas fisik, perlengkapan, dan material yang digunakan perusahaan, serta penampilan petugas. Indikatornya terdiri dari :

1. Fasilitas fisik, Berkaitan dengan letak instansi dan fasilitas gedung yang memadai dalam hal menunjang pelayanan yang diberikan oleh instansi.

2. Perlengkapan prosedur pelayanan, Tersedianya peralatan komputer dan perlengkapan lainnya yang layak dan memadai untuk menunjang pelayanan.

3. Penampilan petugas, Berkenaan dengan penampilan para petugas yang sopan dan rapi dalam memberikan pelayanan. 


\section{Kepuasan Kerja}

Ricahard, Robert dan Gordon (2012) menegaskan bahwa kepuasan kerja berhubungan dengan perasaan atau sikap seseorang mengenai pekerjaan itu sendiri, gaji, kesempatan promosi atau pendidikan, pengawasan, rekan kerja, beban kerja dan lain-lain. Ia melanjutkan pernyataanya bahwa kepuasan kerja berhubungan dengan sikap seeorang mengenai kerja, dan ada beberapa alasan praktis yang membuat kepuasan kerja merupakan konsep yang penting bagi pemimpin. Penelitian menunjukkan pekerja yang puas lebih cenderung bertahan bekerja untuk organisasi. Pekerja yang puas juga cenderung terlibat dalam perilaku organisasi yang melampaui deskripsi tugas dan peran mereka, serta membantu mengurangi beban kerja dan tingkat stress anggota dalam organisasi. Pekerja yang tidak puas cenderung bersikap menentang dalm hubungannya dengan kepemimpinan dan terlibat dalam berbagai perilaku yang kontraproduktif.

Menurut Robbins dan Judge (2013), kepuasan kerja memiliki lima dimensi yaitu:

1) Pekerjaan itu sendiri dengan indikator: tugas, kesempatan belajar, dan tanggung jawab.

2) Gaji saat ini, dengan indikator: sistem penggajian dan keadilan penggajian.

3) Kesempatan promosi, dengan indikator: peluang promosi.

4) Pimpinan, dengan indikator: gaya memimpin.

5) Rekan kerja, dengan indikator: dukungan antar rekan kerja.

Faktor-faktor yang biasa digunakan untuk mengukur kepuasan kerja seorang karyawan menurut Robbins and Judge dalam Puspitawati (2011), yaitu :

1) Pekerjaan itu sendiri (work it self), yaitu merupakan sumber utama kepuasan dimana pekerjaan tersebut memberikan tugas yang menarik, kesempatan untuk belajar, kesempatan untuk menerima tanggung jawab dan kemajuan untuk karyawan.

2) Gaji/ Upah (pay), yaitu merupakan faktor multidimensi dalam kepuasan kerja. Sejumlah upah/ uang yang diterima karyawan menjadi penilaian untuk kepuasan, dimana hal ini bisa dipandang sebagai hal yang dianggap pantas dan layak.

3) Promosi (promotion), yaitu kesempatan untuk berkembang secara intelektual dan memperluas keahlian menjadi dasar perhatian penting untuk maju dalam organisasi sehingga menciptakan kepuasan.

4) Pengawasan (supervision), yaitu merupakan kemampuan penyelia untuk memberikan bantuan teknis dan dukungan perilaku. Pertama adalah berpusat pada karyawan, diukur menurut tingkat dimana penyelia menggunakan ketertarikan personal dan peduli pada karyawan. 
Kedua adalah iklim partisipasi atau pengaruh dalam pengambilan keputusan yang dapat mempengaruhi pekerjaan karyawan.

5) Rekan kerja (workers), yaitu rekan kerja yang kooperatif merupakan sumber kepuasan kerja yang paling sederhana. Kelompok kerja, terutama tim yang kompak bertindak sebagai sumber dukungan, kenyamanan, nasehat, dan bantuan pada anggota individu

\section{Loyalitas}

Loyalitas kerja merupakan salah satu faktor yang mempengaruhi promosi jabatan, karena karyawan yang memiliki loyalitas kerja tinggi dianggap mampu memberikan hasil yang maksimal dalam pencapaian tujuan perusahaan (Hamzah et al, 2013). Loyalitas kerja merupakan kesetiaan karyawan terhadap perusahaan yang akan menimbulkan rasa tanggung jawab, sehingga karyawan akan tetap bertahan dalam perusahaan tersebut walaupun perusahaan dalam keadaan maju atau mundur.

Aspek-aspek loyalitas kerja yang terdapat pada individu dikemukakan oleh Siswanto dalam Soegandhi (2013), yang menitik beratkan pada pelaksanaan kerja yang dilakukan karyawan antara lain. :

1. Taat pada peraturan. Setiap kebijakan yang diterapkan dalam organisasi untuk memperlancar dan mengatur jalannya pelaksanaan tugas oleh manajemen organisasi ditaati dan dilaksanakan dengan baik. Keadaan ini akan menimbulkan kedisiplinan yang menguntungkan organisasi baik intern maupun ekstern.

2. Tanggung jawab pada perusahaan atau organisasi. Karakteristik pekerjaan dan pelaksanaan tugasnya mempunyai konsekuensi yang dibebankan karyawan. Kesanggupan karyawan untuk melaksanakan tugas sebaik-baiknya dan kesadaran akan setiap resiko pelaksanaan tugasnya akan memberikan pengertian tentang keberanian dan kesadaran bertanggungjawab terhadap resiko atas apa yang telah dilaksanakan.

3. Kemauan untuk bekerja sama. Bekerja sama dengan orangorang dalam suatu kelompok akan memungkinkan organisasi dapat mencapai tujuan yang tidak mungkin dicapai oleh orangorang secara invidual.

4. Rasa memiliki, adanya rasa ikut memiliki karyawan terhadap organisasi akan membuat karyawan memiliki sikap untuk ikut menjaga dan bertanggung jawab 
terhadap organisasi sehingga pada akhirnya akan menimbulkan loyalitas demi tercapainya tujuan organisasi.

5. Hubungan antar pribadi, karyawan yang mempunyai loyalitas kerja tinggi mereka akan mempunyai sikap fleksibel ke arah tata hubungan antara pribadi. Hubungan antara pribadi ini meliputi : hubungan sosial diantara karyawan, hubungan yang harmonis antara atasan dan karyawan, situasi kerja dan sugesti dari teman kerja.

6. Kesukaan terhadap pekerjaan, organisasi harus dapat menghadapi kenyataan bahwa karyawannya tiap hari datang untuk bekerjasama sebagai manusia seutuhnya dalam hal melakukan pekerjaan yang akan dilakukan dengan senang hati sebagai indikatornya bisa dilihat dari : keunggulan karyawan dalam bekerja, karyawan tidak pernah menuntut apa yang diterimanya diluar gaji pokok.

Menurut Siswanto (2010) aspek-aspek loyalitas kerja yang terdapat pada individu, menitik beratkan pada pelaksanaan kerja yang dilakukan karyawan antara lain :

1.Taat pada peraturan

2.Tanggung jawab pada perusahaan

3.Kemauan untuk bekerja sama

4.Rasa memiliki

5.Hubungan antar pribadi

6.Kesukaan terhadap pekerjaan. 


\section{Penelitian Terdahulu}

Beberapa hasil penelitian yang relevan dengan penelitian ini yaitu :

Tabel 1 Penelitian Terdahulu Yang Relevan

\begin{tabular}{|c|c|c|c|c|c|}
\hline No & Peneliti & Judul & Metode & Hasil Penelitian & $\begin{array}{c}\text { Posisi } \\
\text { Penelitian }\end{array}$ \\
\hline 1 & $\begin{array}{l}\text { Soegandhi, } \\
\text { Eddy M. } \\
\text { Sutanto, } \\
\text { dan Roy } \\
\text { Setiawan } \\
(2013)\end{array}$ & $\begin{array}{l}\text { Pengaruh kepuasan } \\
\text { kerja dan loyalitas } \\
\text { kerja terhadap } \\
\text { organizational } \\
\text { citizenship behavior } \\
\text { pada karyawan PT. } \\
\text { Surya Timur Sakti } \\
\text { Jatim }\end{array}$ & $\begin{array}{l}\text { Jenis Penelitian } \\
\text { Deskriptif } \\
\text { Kuantitatif } \\
\text { Dengan metode } \\
\text { analisis regresi } \\
\text { linier berganda dan } \\
\text { crosstab, dengan } \\
\text { jenis penelitian } \\
\text { causal research } \\
\text { Metode sampel } \\
\text { menggunakan Non } \\
\text { Probability } \\
\text { Sampling jenis } \\
\text { Quota Sampling }\end{array}$ & $\begin{array}{l}\text { Hasil analisis dari } \\
\text { penelitian ini } \\
\text { bahwa kepuasan } \\
\text { kerja dan loyalitas } \\
\text { kerja berpengaruh } \\
\text { positif terhadap } \\
\text { organizational } \\
\text { citizenship } \\
\text { behavior karyawan } \\
\text { PT. Surya Timur } \\
\text { Sakti Jatim. }\end{array}$ & $\begin{array}{lr}\text { Perbedaan } & \text { dari } \\
\text { penelitian ini } \\
\text { adalah metode } \\
\text { analisis dan } \\
\text { metode } \\
\text { penarikan } \\
\text { sampel. }\end{array}$ \\
\hline 2 & $\begin{array}{l}\text { Nurullaili } \\
\text { dan } \\
\text { Wijayanto } \\
(2013)\end{array}$ & $\begin{array}{l}\text { Analisis } \quad \text { Faktor- } \\
\text { Faktor } \quad \text { Yang } \\
\text { Memengaruhi } \\
\text { Loyalitas } \\
\text { Konsumen } \\
\text { Tupperware }\end{array}$ & $\begin{array}{lr}\text { Jenis penelitian } \\
\text { Kuantitatif } \\
\text { (explanatory } \\
\text { research) dengan } \\
\text { analisis regresi } \\
\text { linier berganda } \\
\text { Sampel memakai } \\
\text { non probability } \\
\text { sampling teknik } \\
\text { puposive sampling. }\end{array}$ & $\begin{array}{l}\text { Hasil analisis dari } \\
\text { penelitian } \\
\text { bahwa variabel } \\
\text { kualitas produk, } \\
\text { harga, promosi, dan } \\
\text { desain merupakan } \\
\text { faktor yang secara } \\
\text { signifikan } \\
\text { berpengaruh } \\
\text { terhadap loyalitas } \\
\text { konsumen }\end{array}$ & $\begin{array}{l}\text { Perbedaan dari } \\
\text { penelitian ini } \\
\text { adalah metode } \\
\text { penelitian } \\
\text { (analisis dan } \\
\text { metode } \\
\text { penarikan } \\
\text { sampel) }\end{array}$ \\
\hline 3 & $\begin{array}{l}\text { Santoso } \\
\text { dan } \\
\text { Oetomo } \\
(2013)\end{array}$ & $\begin{array}{l}\text { Pengaruh Kualitas } \\
\text { Pelayanan Terhadap } \\
\text { Loyalitas } \\
\text { Pelanggang } \\
\text { Laboratorium } \\
\text { Klinik Populer } \\
\text { Surabaya }\end{array}$ & $\begin{array}{l}\text { Jenis penelitian } \\
\text { kuantitatif dengan } \\
\text { analisa regresi linier } \\
\text { berganda, dengan } \\
\text { metode sampel non } \\
\text { probability } \\
\text { sampling }\end{array}$ & $\begin{array}{l}\text { Hasil penelitian } \\
\text { menunjukkan } \\
\text { pengaruh variabel } \\
\text { kualitas pelayanan } \\
\text { yang terdiri bukti } \\
\text { fisik, keandalan, } \\
\text { daya tanggap, } \\
\text { jaminan, dan } \\
\text { empati secara } \\
\text { bersama-sama } \\
\text { (simultan) } \\
\text { berpengaruh } \\
\text { signifikan terhadap } \\
\text { loyalitas pelanggan } \\
\text { Laboratorium } \\
\text { Klinik Populer } \\
\text { Surabaya }\end{array}$ & $\begin{array}{lr}\text { Perbedaan } & \text { dari } \\
\text { penelitian } & \text { ini } \\
\text { adalah } & \text { teknik } \\
\text { analisis } & \text { dan } \\
\text { metode } & \\
\text { penarikan } & \\
\text { sampel } & \end{array}$ \\
\hline
\end{tabular}




\begin{tabular}{|c|c|c|c|c|c|}
\hline 4 & $\begin{array}{l}\text { Maskur, } \\
\text { Qomariah, } \\
\text { dan } \\
\text { Nursaidah } \\
(2016)\end{array}$ & $\begin{array}{lr}\text { Analisis } & \text { Pengaruh } \\
\text { Kualitas } & \text { Pelayanan, } \\
\text { Harga, } & \text { dan } \\
\text { Kepuasan } & \\
\text { Pelanggan } & \\
\text { Terhadap } & \text { Loyalitas } \\
\text { Pelanggan } & \text { (Studi } \\
\text { Kasus r pada } \\
\text { Bengkel rabil } \\
\text { Larasati Lumajang) }\end{array}$ & $\begin{array}{l}\text { Penelitian } \\
\text { Kuantitatif dengan } \\
\text { analisis regresi } \\
\text { linier berganda, uji } \\
\text { asumsi klasik, dan } \\
\text { uji hipotesis (uji F, } \\
\text { uji t, koefesien } \\
\text { determinasi) } \\
\text { Metode sampel } \\
\text { teknik non } \\
\text { probability } \\
\text { sampling } \\
\text { menggunakan } \\
\text { purposive sampling }\end{array}$ & $\begin{array}{l}\text { Menggunakan } \\
\text { regresi dapat } \\
\text { diketahui bahwa } \\
\text { kualitas pelayanan, } \\
\text { harga dan kepuasan } \\
\text { pelanggan } \\
\text { semuanya } \\
\text { berpengaruh positif } \\
\text { terhadap loyalitas } \\
\text { pelanggan, dari uji } \\
\text { F diperoleh hasil } \\
\text { kualitas pelayanan, } \\
\text { harga dan kepuasan } \\
\text { pelanggan, } \\
\text { semuanya } \\
\text { berpengaruh } \\
\text { signifikan secara } \\
\text { simultan terhadap } \\
\text { loyalitas pelanggan, } \\
\text { dari uji t diperoleh } \\
\text { hasil kualitas } \\
\text { pelayanan dan } \\
\text { kepuasan pelanggan, } \\
\text { beperngaruh } \\
\text { signifikan terhadap } \\
\text { loyalitas pelanggan } \\
\text { sedangkan harga } \\
\text { tidak berpengaruh } \\
\text { signifikan terhadap } \\
\text { loyalitas pelanggan }\end{array}$ & $\begin{array}{lr}\text { Perbedaan } & \text { dari } \\
\text { penelitian ini } \\
\text { adalah metode } \\
\text { analisis dan } \\
\text { metode } \\
\text { penarikan } \\
\text { sampel }\end{array}$ \\
\hline 5 & $\begin{array}{l}\text { Sirhan } \\
\text { Fikri, } \\
\text { Wahyu } \\
\text { Wiyani, } \\
\text { dan Agung } \\
\text { Suwandaru } \\
(2016)\end{array}$ & $\begin{array}{lr}\text { Pengaruh } & \text { Kualitas } \\
\text { Pelayanan Terhadap } \\
\text { Kepuasan } \\
\text { Loyalitas } \\
\text { Mahasiswa }\end{array}$ & $\begin{array}{l}\text { Penelitian } \\
\text { Deskriptif } \\
\text { kuantitatif, } \\
\text { Path Analyse, } \\
\text { Penarikan Sampel } \\
\text { teknik Slovin }\end{array}$ & $\begin{array}{l}\text { Hasil penelitian } \\
\text { menunjukan } \\
\text { kualitas pelayanan } \\
\text { berpengaruh } \\
\text { signifikan terhadap } \\
\text { loyalitas }\end{array}$ & $\begin{array}{l}\text { Persamaan } \\
\text { penelitian ini } \\
\text { adalah sama- } \\
\text { sama memakai } \\
\text { analisis path. } \\
\text { Perbedaanya } \\
\text { pada teknik } \\
\text { penarikan } \\
\text { sampel }\end{array}$ \\
\hline 6 & $\begin{array}{l}\text { Agus } \\
\text { Tunggal } \\
\text { Saputra, I } \\
\text { Wayan } \\
\text { Bagia1, Ni } \\
\text { Nyoman } \\
\text { Yulianthini } \\
\text { 2, (2016) }\end{array}$ & $\begin{array}{l}\text { Pengaruh Kepuasan } \\
\text { Kerja Dan Loyalitas } \\
\text { Karyawan Terhadap } \\
\text { Kinerja Karyawan }\end{array}$ & $\begin{array}{l}\text { Jenis Penelitian: } \\
\text { Kuantitatif Kausal } \\
\text { Analisis } \text { Path } \\
\text { Metode penelitian } \\
\text { populasi (populasi } \\
\text { dijadikan sampel / } \\
\text { tidak ada penarikan } \\
\text { sampel) }\end{array}$ & $\begin{array}{lr}\text { Hasil } & \text { penelitian } \\
\text { menunjukkan } & \text { ada } \\
\text { pengaruh } & \text { positif } \\
\text { dari (1) } & \text { kepuasan } \\
\text { kerja dan } & \text { loyalitas } \\
\text { karyawan } & \text { terhadap } \\
\text { kinerja } & \text { karyawan, } \\
(2) \text { kepuasan } & \text { kerja } \\
\text { terhadap } & \text { kinerja } \\
\text { karyawan, } & (3) \\
\text { loyalitas } & \text { karyawan } \\
\text { terhadap } & \text { kinerja } \\
\text { karyawan, } & (4) \\
\text { kepuasan } & \text { kerja } \\
\text { terhadap } & \text { loyalitas }\end{array}$ & $\begin{array}{l}\text { Perbedaan dari } \\
\text { penelitian ini } \\
\text { adalah metode } \\
\text { pengambilan } \\
\text { sampel, disini } \\
\text { menggunakan } \\
\text { populasi } \\
\text { seluruhnya } \\
\text { (penelitian } \\
\text { populasi) }\end{array}$ \\
\hline
\end{tabular}




\begin{tabular}{|c|c|c|c|c|c|}
\hline & & & & $\begin{array}{l}\text { karyawan PT Sun } \\
\text { Star Motor Cabang } \\
\text { Negara }\end{array}$ & \\
\hline 7 & $\begin{array}{l}\text { Dita Putri } \\
\text { Anggraeni, } \\
\text { Srikandi } \\
\text { Kumadji, } \\
\text { dan Sunarti } \\
(2016)\end{array}$ & $\begin{array}{lr}\text { Pengaruh } & \text { Kualitas } \\
\text { Produk } & \text { Terhadap } \\
\text { Kepuasan } & \text { dan } \\
\text { Loyalitas } & \\
\text { Pelanggan } & \end{array}$ & $\begin{array}{l}\text { Jenis Penelitian } \\
\text { kuantitatif } \\
\text { explanatory } \\
\text { research, dengan } \\
\text { analisis deskriptif } \\
\text { dan analisis jalur } \\
\text { (path analyse), } \\
\text { teknik sampel } \\
\text { purposive sampling }\end{array}$ & $\begin{array}{l}\text { Hasil penelitian } \\
\text { menunjukkan } \\
\text { bahwa kualitas } \\
\text { produk } \\
\text { berpengaruh } \\
\text { signifikan terhadap } \\
\text { kepuasan dan } \\
\text { pelanggan pelanggan, } \\
\text { loyalitas pelasan } \\
\text { serta kepuasa } \\
\text { pelanggan } \\
\text { berpengaruh } \\
\text { signifikan terhadap } \\
\text { loyalitas pelanggan }\end{array}$ & $\begin{array}{l}\text { Persamaan } \\
\text { penelitian ini } \\
\text { adalah sama- } \\
\text { sama memakai } \\
\text { analisis path. } \\
\text { Perbedaan dari } \\
\text { penelitian ini } \\
\text { adalah pada } \\
\text { teknik penarikan } \\
\text { sampel. }\end{array}$ \\
\hline
\end{tabular}

\section{Kerangka Pemikiran Konseptual}

Kualitas layanan merupakan bagian terpenting dalam berkerja agar tercipta kepuasan kerja, dan kepuasan kerja akan membentuk sikap loyalitas, maka dari itu penulis membuat kerangka konsep penelitian dengan mediated path model sebagai berikut:

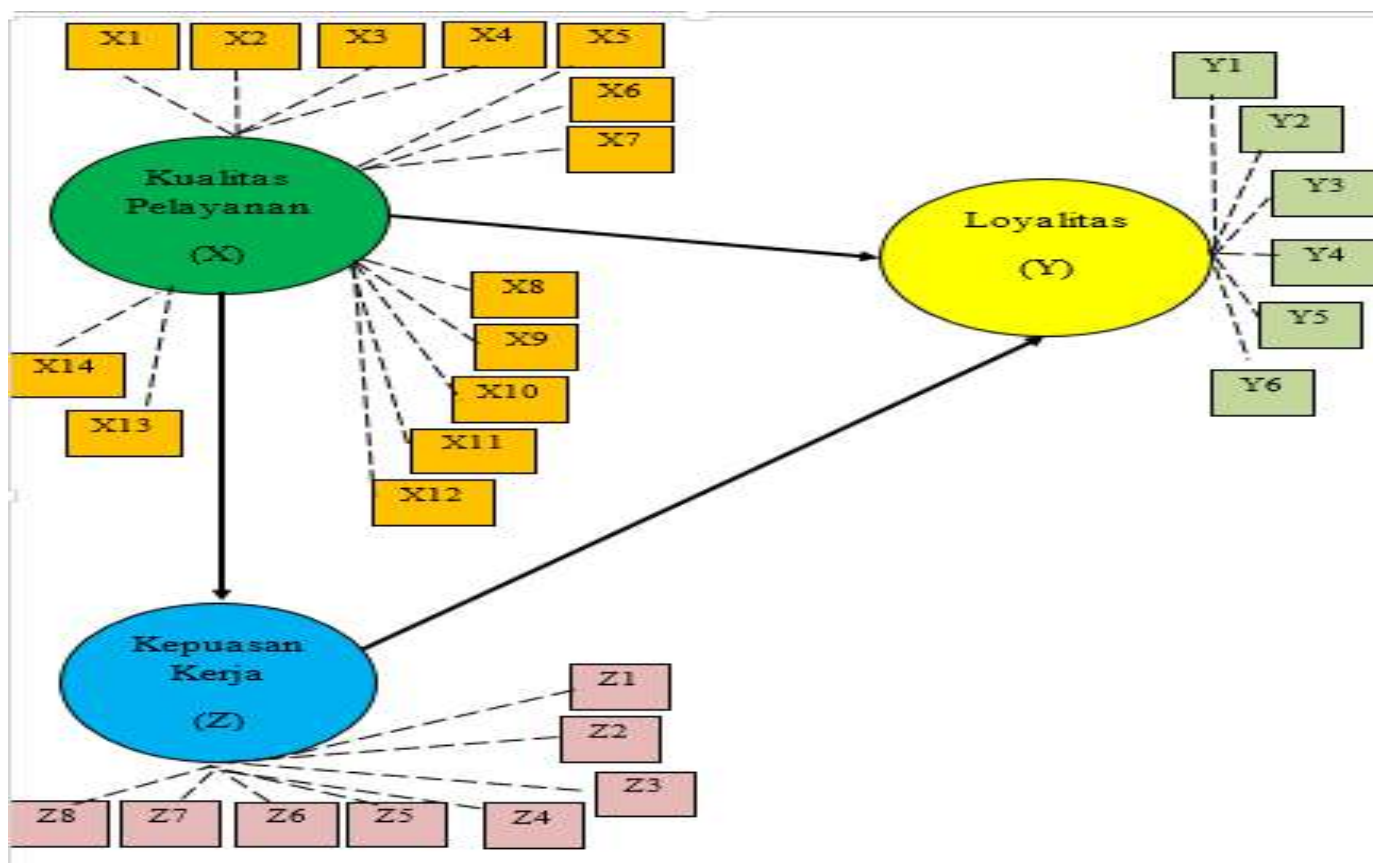

Gambar 1 Kerangka pikir 


\section{METODE PENELITIAN}

\section{Desain Penelitian}

Penelitian ini merupakan penelitian kuantitatif, Penelitian ini terdiri dari dua variabel yaitu Motivasi kerja sebagai variabel bebas (X), kepuasan kerja sebagai variabel intervening $(\mathrm{Z})$, dan loyalitas sebagai variabel terikat $(\mathrm{Y})$.

\section{Teknik Pengambilan Data}

Karena analisis statistik penelitian ini dilakukan dengan Structural Equation Modeling (SEM), teknik pengambilan sampel yang digunakan adalah non probability sampling dengan pendekatan purposive sampling yaitu peneliti memilih sampel purposive secara subyektif (Ferdinand, 2006), penentuan jumlah sampel menggunakan rumus (Ferdinand, 2006): Jumlah sampel $=$ jumlah indikator x 5 sampai 10 Dalam penelitian ini terdapat 28 indikator, maka jumlah sampel yang digunakan adalah: Sampel minimum = Jumlah indikator X $5=28$ X $5=140$ responden Sampel maksimum $=$ Jumlah indikator X $10=28 \times 10=280$ responden, Selanjutnya Hair, dkk (dalam Ferdinand, 2006) menemukan bahwa ukuran sampel yang sesuai untuk Structural Equation Modeling (SEM) adalah antara 100 - 200 sampel. Untuk pembulatan, dengan mengacu pada pendapat Hair tersebut, maka jumlah responden yang digunakan dalam penelitian ini adalah jumlah sampel minimum ditambah 5, yakni 140 ditambah 5, menjadi 145 responden.

\section{Definisi Operasional}

Untuk memberikan gambaran yang lebih jelas tentang variabel penelitian, maka disajikan tabel sebagai berikut:

\section{Tabel 2}

\section{Definisi Operasional Variabel}

\begin{tabular}{|c|c|c|c|c|}
\hline Variabel & Konsep Variabel & Indikator & Sumber & Skala Ordinal \\
\hline \multirow{3}{*}{$\begin{array}{c}\text { Kualitas } \\
\text { Pelayanan } \\
\text { (X) }\end{array}$} & \multirow{3}{*}{$\begin{array}{l}\text { Suatu kondisi } \\
\text { dinamis yang } \\
\text { berhubungan dengan }\end{array}$} & $\begin{array}{l}\text { Konsistensi kinerja } \\
\text { (performance) }\end{array}$ & \multirow{3}{*}{$\begin{array}{c}\text { Parasuraman, } \\
\text { Zeithaml, dan Berry } \\
\text { (1988) dalam } \\
\text { Tjiptono dan } \\
\text { Chandra (2007) }\end{array}$} & \multirow{3}{*}{ Ordinal } \\
\hline & & $\begin{array}{l}\text { Sifat dapat dipercaya } \\
\text { (dependability) }\end{array}$ & & \\
\hline & & $\begin{array}{l}\text { Kesediaan dan } \\
\text { kesiapan petugas }\end{array}$ & & \\
\hline
\end{tabular}




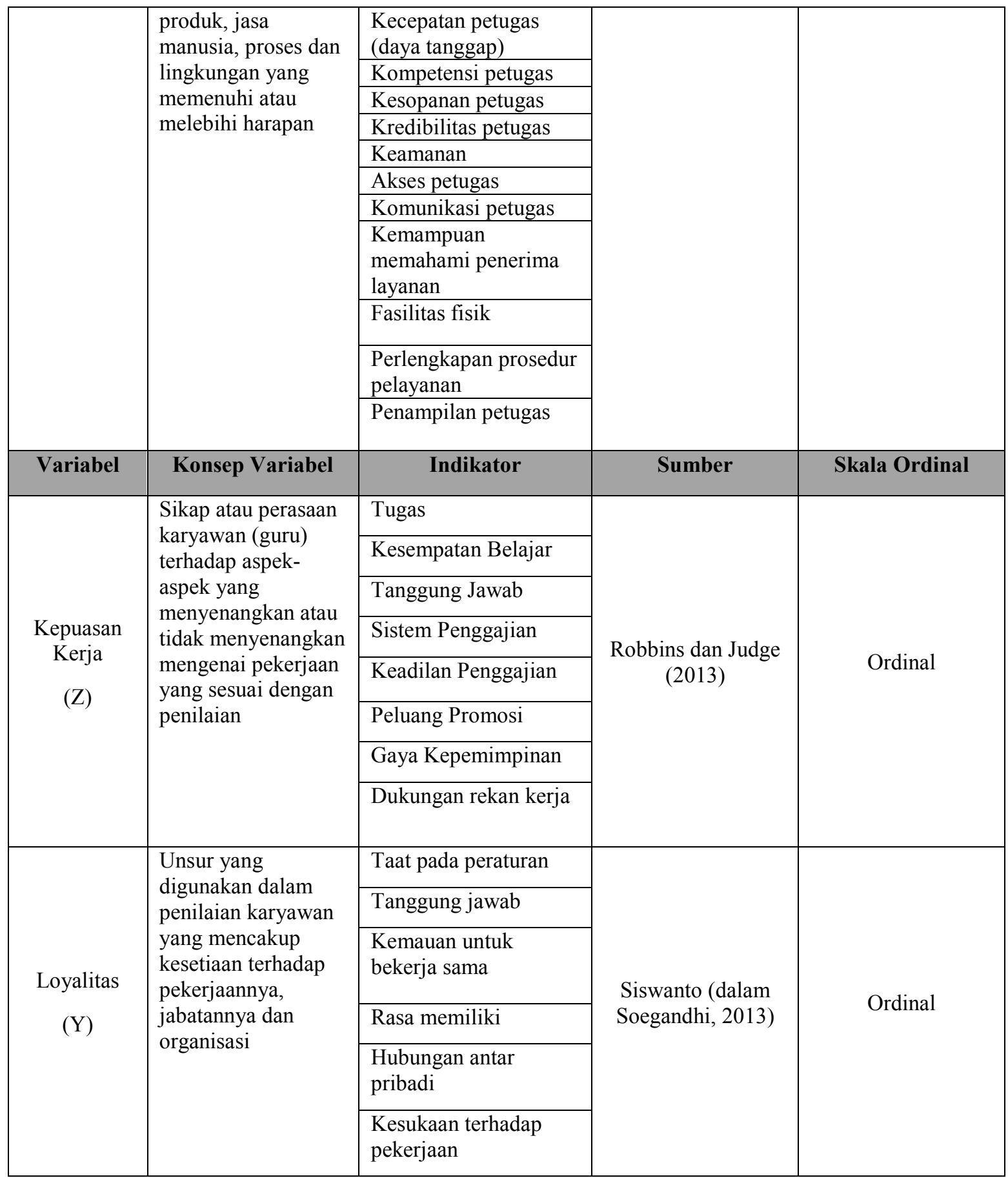

\section{Teknik Analisis Data}

Model ini bertujuan untuk mengetahui pengaruh langsung maupun tidak langsung seperangkat variabel bebas (eksogen) terhadap variabel (endogen). Koefisien jalur (path) adalah koefisien regresi yang distandartkan, yaitu koefisien regresi yang dihitung dari basis 
data yang telah diset dalam angka baku (Z-score). Analisis ini dibantu dengan bantuan software SmartPLS 3.0, dengan ketentuan uji F pada Alpha $=0,05$ atau $\mathrm{p} \leq 0,05$ sebagai taraf signifikansi F (sig. F) sedangkan untuk uji T taraf signifikansi Alpha $=0,05$ atau $\mathrm{p} \leq$ 0,05 yang dimunculkan kode (sig.T) dimana hal tersebut digunakan untuk melihat signifikansi pengaruh tidak langsung dari variabel bebas terhadap variabel terikat.

\section{HASIL DAN PEMBAHASAN}

\section{Analisis Causal Modeling (Path Analysis)}

Model Pengukuran untuk analisis causal modeling dari masing-masing variabel yaitu kualitas layanan, kepuasan kerja, dan loyalitas diolah menggunakan alat uji SmartPLS 3.0,

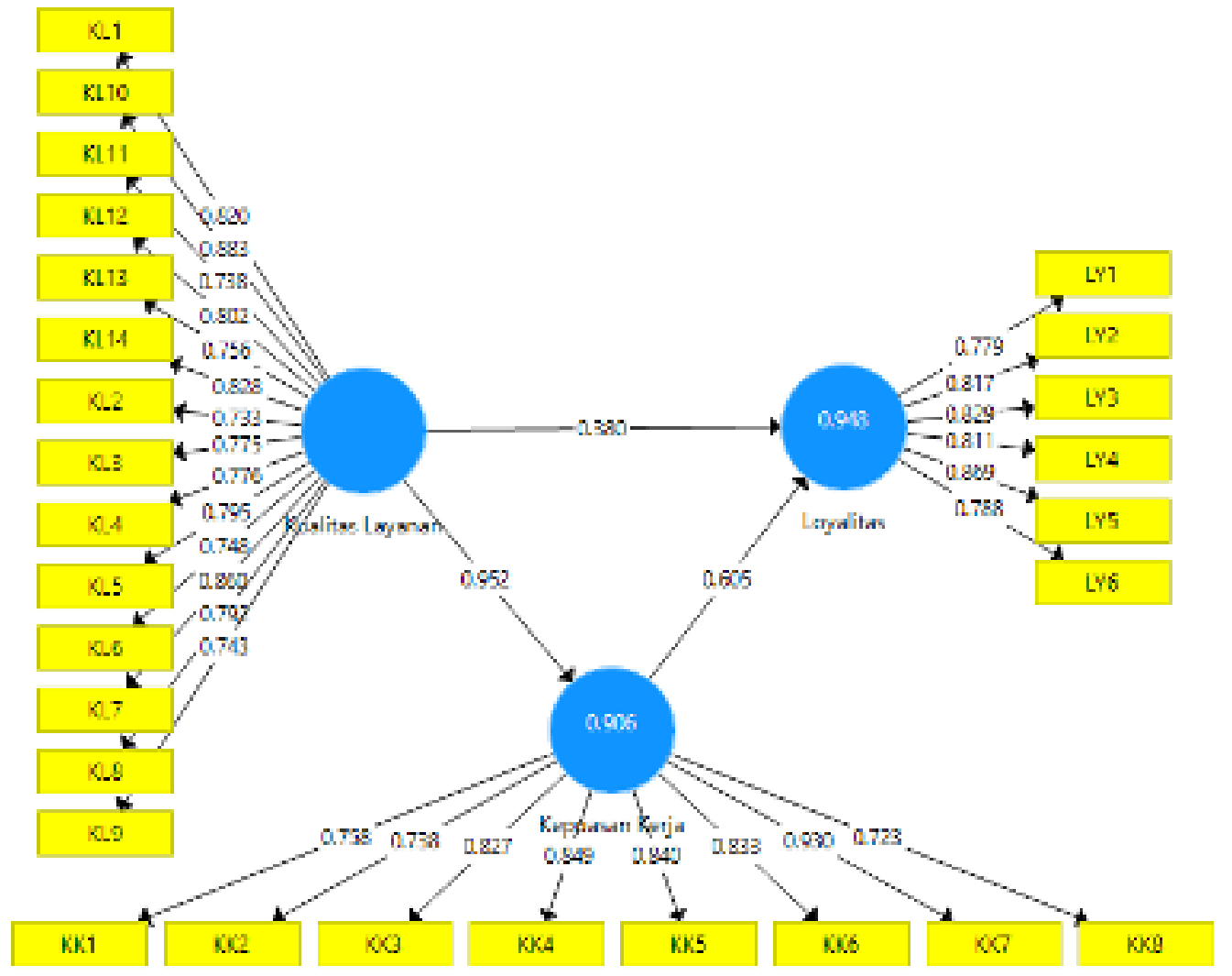

Gambar 2 Jalur Model Hasil Analisis SmartPLS 3.0

Sumber: Data Kuisioner, untuk tesis ini, diolah 2018 
Dari hasil analisis ini dapat dilihat bahwa setiap variabel memiliki nilai outer loadings yang signifikan dengan probabilitas $0.000(0.000<0.05)$. Dengan demikian semua indikator dapat diterima.

Pengujian terhadap nilai residual mengidentifikasikan bahwa secara signifikan dapat diterima, nilai residual yang ditetapkan adalah \pm 2.58 pada taraf signifikan $5 \%$ (Hair, 2006). Sedangkan hasil yang diolah menggunakan SmartPLS 3.0 didapatkan hasil menunjukkan tidak terdapat nilai residual yang melibihi 2.58

Uji reliabilitas dilakukan untuk mengukur tingkat konsistensi antara hasil pengamatan dengan instrumen atau alat ukur yang digunakan pada waktu yang berbeda, dengan kata lain reliabiitas berkaitan dengan keandalan suatu indikator mengenai informasi yang ada pada indikator dengan konsisten. Tingkat reliabilitas yang diterima adalah $\geq 0.70$. Pada uji validitas didasarkan pada ketentuan valid jika $r$ hitung $>r$ tabel, dan tidak valid jika $\mathrm{r}$ hitung $<\mathrm{r}$ tabel. Responden yang digunakan berjumlah 145 responden, dengan signifikan 5\%, maka $\mathrm{df}=\mathrm{n}-2(\mathrm{df}=145-2=143)$, didapat angka $\mathrm{r}$ tabel yaitu 0,1362 . Hasil pengukuran dapat dilihat pada tabel berikut:

Tabel 3

\section{Construct Reliability and Validity}

\begin{tabular}{|l|c|c|c|c|}
\hline & $\begin{array}{c}\text { Cronbach's } \\
\text { Alpha }\end{array}$ & rho_A & $\begin{array}{c}\text { Composite } \\
\text { Reliability }\end{array}$ & $\begin{array}{c}\text { Average } \\
\text { Variance } \\
\text { Extracted } \\
\text { (AVE) }\end{array}$ \\
\hline Kepuasan Kerja & 0.926 & 0.931 & 0.940 & 0.664 \\
\hline $\begin{array}{l}\text { Kualitas } \\
\text { Layanan }\end{array}$ & 0.953 & 0.955 & 0.959 & 0.625 \\
\hline Loyalitas & 0.899 & 0.902 & 0.923 & 0.666 \\
\hline
\end{tabular}

Sumber: Data Kuisioner, diolah 2018 menggunakan SmartPLS 3.0

Pada variabel $\mathrm{X}$ terbukti valid karena nilai $\mathrm{r}$ hitung pada tabel correlation lebih besar bila dibandingkan dengan nilai $r$ tabel. Pada variabel $\mathrm{Y}$ terbukti valid karena nilai $\mathrm{r}$ hitung pada tabel correlation lebih besar bila dibandingkan dengan nilai $r$ tabel. Dan pada variabel $\mathrm{Z}$ terbukti valid karena nilai $\mathrm{r}$ hitung pada tabel correlation lebih besar bila dibandingkan dengan nilai $\mathrm{r}$ tabel, didukung dengan hasil Latent Variable Correlations, pada tabel berikut: 
Tabel 4

Latent Variable Correlations

\begin{tabular}{|l|c|c|c|}
\hline & Kepuasan Kerja & Kualitas Layanan & Loyalitas \\
\hline $\begin{array}{l}\text { Kepuasan Kerja } \\
\text { Kualitas } \\
\text { Layanan }\end{array}$ & 1.000 & 0.952 & 0.966 \\
\hline Loyalitas & 0.952 & 1.000 & 0.956 \\
\hline
\end{tabular}

Sumber: Data Kuisioner, diolah 2018 menggunakan SmartPLS 3.0

\section{Analisis Path Coefficients}

Hasil analisis Path Coefficients atau koefisien regresi standar (standar z) yang menunjukkan pengaruh variabel eksogen terhadap endogen, Untuk mengetahui apakah ada atau tidaknya pengaruh langsung antara variabel independen terhadap intervening dan variabel intervening terhadap dependen, maupun pengaruh tidak langsung variabel independen dependen melalui intervening, dilakukan uji analisis jalur (path analysis) menggunakan SmartPLS 3.0 yaitu dengan strategi causal step (path of coefficients). Dilakukan dengan prosedur Bootrapping. Dapat dilihat pada tabel berikut:

Tabel 5

\section{Path Coefficients}

\begin{tabular}{|l|c|c|c|c|c|}
\hline & $\begin{array}{c}\text { Original } \\
\text { Sample } \\
(\mathbf{O})\end{array}$ & $\begin{array}{c}\text { Sample } \\
\text { Mean } \\
\mathbf{( M )}\end{array}$ & $\begin{array}{c}\text { Standard } \\
\text { Deviation } \\
\text { (STDEV) }\end{array}$ & $\begin{array}{c}\text { T Statistics } \\
(\mid \mathbf{O} / \text { STDEV } \mid)\end{array}$ & $\begin{array}{c}\text { P } \\
\text { Values }\end{array}$ \\
\hline $\begin{array}{l}\text { Kualitas Layanan -> } \\
\text { Kepuasan Kerja }\end{array}$ & 0.952 & 0.952 & 0.005 & 186.953 & 0.000 \\
\hline $\begin{array}{l}\text { Kepuasan Kerja -> } \\
\text { Loyalitas }\end{array}$ & 0.605 & 0.604 & 0.059 & 10.297 & 0.000 \\
\hline $\begin{array}{l}\text { Kualitas Layanan -> } \\
\text { Loyalitas }\end{array}$ & 0.380 & 0.381 & 0.061 & 6.254 & 0.000 \\
\hline
\end{tabular}

Sumber: Data Kuisioner, diolah 2018 memakai SmartPLS 3.0

Pada strategi causal step, kriteria hipotesis (Ha) diterima apabila Sig $<0.05$ (P Values) untuk pengaruh langsung baik secara simultan (nilai F-hitung) maupun pengaruh parsial. Untuk path coefficients, nilai koefisen jalur atau besarnya hubungan atau pengaruh konstruk laten. 
Tabel 6

f Square

\begin{tabular}{|l|c|c|c|}
\hline & $\begin{array}{c}\text { Kepuasan } \\
\text { Kerja }\end{array}$ & $\begin{array}{c}\text { Kualitas } \\
\text { Layanan }\end{array}$ & Loyalitas \\
\hline Kepuasan Kerja & & & 0.659 \\
\hline Kualitas Layanan & 9.610 & & 0.261 \\
\hline Loyalitas & & & \\
\hline
\end{tabular}

Sumber: Data Kuisioner, diolah 2018 memakai SmartPLS 3.0

Hasil pengkuran menunjukkan hasil yang signifikan dan telah memenuhi syarat causal step, selanjutnya berdasarkan data ini akan dilakukan pengujian hipotesis yang akan diajukan dalam penelitian ini.

\section{Pembahasan Hasil Penelitian}

\section{Pengaruh Kualitas Layanan terhadap Kepuasan Kerja}

Berdasarkan hasil perhitungan variabel kualitas layanan mempunyai pengaruh yang positif dan signifikan terhadap kepuasan kerja pada tingkat kesalahan $0.05(\alpha=5$ $\%$, hal ini dibuktikan dengan besarnya koefisien path sebesar 0.952 dengan probabilitas $0.000(0.000<0.05)$, besarnya sumbangan (kontribusi) variabel kualitas layanan terhadap kepuasan kerja dapat dilihat dari nila R square yaitu sebesar 0.906. Ini artinya bahwa 90.6 \% variabel kepuasan kerja dipengaruhi oleh kualitas layanan, sedangkan sisanya $9.4 \%$ dipengaruhi oleh variabel-variabel lain yang tidak dibahas dalam penelitian ini.

\section{Pengaruh Kualitas Layanan terhadap Loyalitas}

Berdasarkan hasil perhitungan variabel kualitas layanan mempunyai pengaruh yang positif dan signifikan terhadap loyalitas pada tingkat kesalahan 0.05 ( $\alpha=5 \%$ ), hal ini dibuktikan dengan besarnya koefisien path sebesar 0.380 dengan probabilitas 0.000 $(0.000<0.05)$, besarnya sumbangan (kontribusi) variabel kualitas layanan terhadap loyalitas dapat dilihat dari nila $\mathrm{R}$ square yaitu sebesar 0.948 . Ini artinya bahwa $94.8 \%$ variabel kepuasan kerja dipengaruhi oleh kualitas layanan, sedangkan sisanya $5.2 \%$ dipengaruhi oleh variabel-variabel lain yang tidak dibahas dalam penelitian ini. 


\section{Pengaruh Langsung, Tidak Langsung, dan Total Antar Variabel}

Analisis jalur (path analysis) digunakan untuk melihat akibat (effect) langsung dan tidak langsung dari suatu variabel yang di hipotesiskan sebagai penyebab (causes) terhadap variabel yang diperlakukan sebagai akibat (effect). Hal ini dapat menjelaskan bahwa analisis jalur dapat digunakan untuk menemukan penjelasan mengenai pola hubungan langsung dan tidak langsung. Melalui gambaran analisis jalur (path analysis) pada setiap hubungan dua variabel, dimana hubungan itu memiliki pengaruh langsung atau tidak langsung.

Pengaruh langsung adalah pengaruh variabel bebas terhadap variabel terikat secara langsung tanpa melalui variabel lain. Pengaruh tidak langsung adalah pengaruh variabel bebas terhadap variabel terikat melalui variabel lain, kemudian terakhir adalah mengetahui pengaruh total (total effect) antar variabel dalam model digunakan untuk membandingkan besarnya pengaruh setiap variabel, sebagaimana dalam tabel berikut:

\section{Tabel 7}

\section{Direct Effect, Indirect Effect, and Total Effect}

\begin{tabular}{|l|c|c|c|c|}
\hline Variabel Bebas & Variabel Terikat & Direct Effect & Indirect Effect & Total Effect \\
\cline { 1 - 3 } Kualitas Layanan & \multirow{2}{*}{ Loyalitas } & 0.380 & 0.575 & 0.956 \\
\cline { 1 - 3 } & & 0.605 & & 0.605 \\
\hline
\end{tabular}

Sumber: Data Kuisioner, diolah 2018 memakai SmartPLS 3.0

Berdasarkan tabel 7 menunjukkan bahwa pengaruh total lebih besar dibandingkan pengaruh langsung pada variabel kualitas layanan terhadap loyalitas. Hal ini berarti variabel kualitas layanan mampu memperkuat variabel kepuasan kerja dan variabel loyalitas.

Besarnya pengaruh tidak langsung dari kualitas layanan terhadap loyalitas melalui kepuasan kerja adalah sebesar 0.575 . Hubungan kualitas layanan terhadap loyalitas lebih memperkuat pengaruh secara tidak langsung yaitu sebesar 0.575 sedangkan pengaruh secara langsung yaitu sebesar 0.380 sehingga memiliki total pengaruh (total effect) sebesar 0.956 . 


\section{Pengujian Hipotesis}

\section{Pengujian Hipotesis Pertama (H1)}

Kualitas layanan berpengaruh signifikan terhadap loyalitas guru di Sekolah Islam Terpadu. Dari tabel 5 diketahui bahwa nilai probability dari variabel kualitas layanan terhadap loyalitas adalah 0.000 dengan t statistik 6.254, artinya variabel kualitas layanan berpengaruh secara positif dan signifikan terhadap loyalitas. Jika kualitas layanan berjalan dengan baik, maka hal ini akan mendorong guru maupun karyawan pada tingkat loyalitas yang maksimal.

Hasil diatas sejalan dengan teori Pujawan (2010) yang mendefinisikan kualitas pelayanan (service quality) sebagai hasil persepsi dan perbandingan antara harapan pelanggan dengan kinerja aktual pelayanan yang terdapat 2 (dua) faktor utama yang mempengaruhi kualitas jasa, yaitu expected service (pengalaman yang diharapkan) dan perceived service (pelayanan yang diterima).

Hasil penelitian juga sejalan juga dengan hasil penelitian yang dilakukan oleh Fikri, Wiyani, dan Suwandaru (2016) kualitas pelayanan merupakan faktor terpenting dalam meningkatkan sikap loyalitas mahasiswa, demikian juga halnya dalam penelitian Maskur, Qomariah, dan Nursaidah (2016) diketahui bahwa kualitas pelayanan, harga dan kepuasan pelanggan semuanya berpengaruh positif terhadap loyalitas pelanggan, dari uji $\mathrm{F}$ diperoleh hasil kualitas pelayanan, harga dan kepuasan pelanggan, semuanya berpengaruh signifikan secara simultan terhadap loyalitas pelanggan, dari uji $\mathrm{t}$ diperoleh hasil kualitas pelayanan dan kepuasan pelanggan, beperngaruh signifikan terhadap loyalitas pelanggan sedangkan harga tidak berpengaruh signifikan terhadap loyalitas pelanggan. Selanjutnya penelitian yang dilakukan oleh Santoso dan Oetomo (2013) pengaruh variabel kualitas pelayanan yang terdiri bukti fisik, keandalan, daya tanggap, jaminan, dan empati secara bersama-sama (simultan) berpengaruh signifikan terhadap loyalitas pelanggan Laboratorium Klinik Populer Surabaya, demikian halnya penelitian yang dilakukan oleh Zakiy (2017), hasil dari penelitian menyatakan bahwa kepuasan nasabah mampu memediasi secara penuh (full mediation) pengaruh kualitas layanan terhadap sikap loyalitas nasabah Bank Syariah. Juga memperkuat hasil penelitian oleh Hadiwidjaja (2017) bahwa kualitas pelayanan termasuk dalam kategori baik dan tinggi, namun loyalitas nasabah dalam kategori sedang. 


\section{Pengujian Hipotesis Kedua (H2)}

Kepuasan kerja berpengaruh signifikan terhadap loyalitas di Sekolah Islam Terpadu. Dari tabel 5 diketahui bahwa nilai probability dari variabel kepuasan kerja terhadap loyalitas adalah 0.000 dengan t statistik 10.297, artinya variabel kepuasan kerja berpengaruh secara positif dan signifikan terhadap loyalitas. Jika kepuasan kerja maksimal dirasakan oleh para guru maupun karyawan, maka hal ini akan meningkatkan sikap loyalitas pada guru maupun karyawan, hal ini lebih penting, berdasarkan tabel 4.25 pengaruh terbesar dalam menimbulkan sikap loyalitas diperoleh dari kepuasan kerja dibandingkan kualitas layanan.

Hasil diatas sejalan dengan terosi Ricahard, Robert dan Gordon (2012) menegaskan bahwa kepuasan kerja berhubungan dengan perasaan atau sikap seseorang mengenai pekerjaan itu sendiri, gaji, kesempatan promosi atau pendidikan, pengawasan, rekan kerja, beban kerja dan lain-lain. Ia melanjutkan pernyataanya bahwa kepuasan kerja berhubungan dengan sikap seeorang mengenai kerja, dan ada beberapa alasan praktis yang membuat kepuasan kerja merupakan konsep yang penting bagi pemimpin. Penelitian menunjukkan pekerja yang puas lebih cenderung bertahan bekerja untuk organisasi. Pekerja yang puas juga cenderung terlibat dalam perilaku organisasi yang melampaui deskripsi tugas dan peran mereka, serta membantu mengurangi beban kerja dan tingkat stress anggota dalam organisasi. Pekerja yang tidak puas cenderung bersikap menentang dalm hubungannya dengan kepemimpinan dan terlibat dalam berbagai perilaku yang kontraproduktif.

Bangun (2012) menyatakan bahwa dengan kepuasan kerja seorang pegawai dapat merasakan pekerjaannya apakah menyenangkan atau tidak menyenangkan untuk dikerjakan. Wilson Bangun mengutip pendapat Wexley dan Yukl (2012) mengatakan bahwa kepuasan kerja merupakan generalisasi sika-sikap terhadap pekerjaannya. Bermacam-macam sikap seseorang terhadap pekerjaannya mencerminkan pengalaman yang menyenangkan dan tidak menyenangkan dalam pekerjaannya mencerminkan pengalamannya serta harapan-harapan terhadap pengalaman masa depan. Pekerjaan itu memberi kepuasan bagi pemangkunya. Kejadian sebaliknya, ketidakpuasan akan diperoleh bila suatu pekerjaan tidak menyengkan untuk dikerjakan. 
Hasil penelitian juga sejalan dengan hasil penelitian yang dilakukan oleh Soegandhi, Sutanto, dan Setiawan (2013) Hasil analisis dari penelitian ini bahwa kepuasan kerja dan loyalitas kerja memiliki pengaruh positif terhadap organizational citizenship behavior karyawan PT. Surya Timur Sakti Jatim. Demikian halnya penelitian yang dilakukan oleh Saputra, Bagia, Yulianthini (2016) hasil penelitian menunjukkan ada pengaruh positif dari kepuasan kerja dan loyalitas karyawan terhadap kinerja karyawan, kepuasan kerja terhadap kinerja karyawan, loyalitas karyawan terhadap kinerja karyawan, dan kepuasan kerja terhadap loyalitas karyawan PT Sun Star Motor Cabang Negara.

Hasil uji hipotesis kedua juga memperkuat penelitian yang dilakukan oleh Putra dan Wardhana (2016) bahwa tingkat pelayanan belum sesuai dengan harapan pelanggan, terdapat perbedaan yang menunjukan adanya kesenjangan antara dua perspektif penilaian yaitu antara tingkat kinerja (performance) dan tingkat harapan (importance) atau kualitas ideal yang diharapkan

\section{Pengujian Hipotesis Ketiga (H3)}

Kualitas layanan dan kepuasan kerja berpengaruh signifikan terhadap loyalitas guru di Sekolah Islam Terpadu, berdasarkan tabel 7 didapatkan hasil bahwa variabel kualitas layanan dan kepuasan kerja berpengaruh signifikan, baik pengaruh langsung kualitas layanan terhadap loyalitas maupun kualitas layanan terhadap loyalitas melalui variabel kepuasan kerja, ini terlihat dari hasil direct effect kualitas layanan terhadap loyalitas dengan nilai 0.380 dan lebih kuat melalui indirect effect (melalui variabel kepuasan kerja) dengan nilai 0.575 , sehingga mendapatkan total effect dengan nilai 0.956. Jika kualitas layanan yang diberikan sekolah terhadap guru maupun karyawan mampu menumbukan kepuasan kerja maka sikap loyalitas akan meningkat.

Hasil diatas sejalan dengan teori Hasibuan (2011), loyalitas adalah Kesetiaan dicerminkan oleh kesediaan karyawan menjaga dan membela organisasi di dalam maupun di luar pekerjaan dari rongrongan orang yang tidak bertanggung jawab. Menurut Meyer dan Herscovits, loyalitas merupakan kondisi psikologis yang mengikat karyawan dan perusahaannya.

Hasil penelitian juga sejalan dengan hasil penelitian oleh Shandra dan Murwatiningsih (2016) bahwa kualitas pelayanan berpengaruh signifikan terhadap 
loyalitas konsumen melalui kepuasan konsumen, brand image berpengaruh signifikan terhadap loyalitas konsumen melalui kepuasan konsumen, dan harga berpengaruh signifikan terhadap loyalitas konsumen melalui kepuasan konsumen, kualitas pelayanan berpengaruh signifikan melalui variabel kepuasan. Begitupu penelitian oleh Anggraeni, Kumadji, dan Sunarti (2016) hasil penelitian menunjukkan bahwa kualitas produk berpengaruh signifikan terhadap kepuasan pelanggan dan loyalitas pelanggan, serta kepuasan pelanggan berpengaruh signifikan terhadap loyalitas pelanggan.

Hasil diatas juga memperkuat hasil penelitian oleh Zakiy (2017) bahwa kepuasan nasabah mampu memediasi secara penuh (full mediation) pengaruh kualitas layanan terhadap loyalitas nasabah Bank Syariah. Variabel kepuasan mampu menjadi penguat pengaruh variabel kualitas layanan terhadap variabel loyalitas.

\section{SIMPULAN}

Berdasarkan analisis data dan pembahasan maka dapat disimpulkan sebagai berikut:

1. Kualitas layanan memiliki pengaruh secara positif dan signfikan langsung terhadap loyalitas. Pengaruh lebih kuat nilainya yaitu pengaruh tidak langsung dari variabel kualitas layanan terhadap loyalitas melalui variabel kepuasan kerja sebagai variabel intervening.

2. Kepuasan kerja sebagai variabel intervening berpengaruh positif dan signifikan terhadap loyalitas, pengaruh lebih kuat terjadi pada pengaruh langsung dari variabel kepuasan kerja terhadap loyalitas.

3. Kualitas layanan berpengaruh signifikan secara langsung maupun melalui kepuasan kerja sebagai pemediasi terhadap loyalitas. Namun dari keduanya diketahui bahwa pengaruh lebih kuat nilainya terjadi pada pengaruh tidak langsung melalui variabel kepuasan kerja sebagai variabel intervening.

\section{DAFTAR PUSTAKA}

Anggraeni, Dita Putri. Kumadji, Srikandi dan Sunarti. 2016. Pengaruh Kualitas Produk Terhadap Kepuasan Dan Loyalitas Pelanggan (Survei pada Pelanggan Nasi Rawon di Rumah Makan Sakinah Kota Pasuruan). Jurnal Administrasi Bisnis. Volume 37. Nomor 1. 2016: 171-177. 
Bangun, Wilson. 2012. Manajemen Sumber Daya Manusia. Erlangga. Jakarta.

Ferdinand. Augusty, 2006. Metode Penelitian Manajemen: Pedoman Penelitian untuk skripsi, Tesis dan Disertai Ilmu Manajemen. Semarang: Universitas Diponegoro.

Fikri, Sirhan, Wahyu Wiyani, dan Agung Suwandaru 2016 Pengaruh Kualitas Pelayanan Terhadap Kepuasan Dan Loyalitas Mahasiswa (Studi pada Mahasiswa Strata I Fakultas Ilmu Sosial dan Ilmu PolitikUniversitas Merdeka Malang), Jurnal Bisnis dan Manajemen Vol. 3 No.1, Januari 2016

Hair, J.F. JR., Anderson, R.E, Tatham, R.L. \& Black, W.C. 2006.

Multivariate Data Analysis.Six Edition. New Jersey : Pearson Educational, Inc Hamzah, Febrian Muriko. Al Musadieq, Mochamad. Hakam, M Soe`oed. 2013. Pengaruh Senioritas Dan Loyalitas Terhadap Promosi (Studi Pada Karyawan PT. Pembangunan Perumahan DVO III Surabaya). Jurnal Administrasi Bisnis. Volume 6. Nomor 2. 2013: 1-8.

Maskur, Muhammad. Qomariah, Nurul dan Nursaidah. 2016. Analisis Pengaruh Kualitas Pelayanan, Harga, Dan Kepuasan Pelanggan Terhadap Loyalitas Pelanggan (Studi Kasus pada Bengkel Mobil Larasati Lumajang). Jurnal Sains Manajemen \& Bisnis Indonesia. Volume 6. Nomor 2. 2016: 212-221.

Nurullaili dan Wijayanto, Andi. 2013. Analisis Faktor-Faktor Yang Mempengaruhi Loyalitas Konsumen Tupperware (Studi Pada Konsumen Tupperware di Universitas Dipenogoro). Jurnal Administrasi Bisnis. Volume 2. Nomor 1. 2013: 89-97.

Parasuraman, A., Berry, L.L., and Zeithaml, A.V., 1988, "SERVQUAL: A Multiple Item Scale for Measuring Consumer Perceptions of Service Quality”, Journal of Retailing, Vol. 64, No. 1, Spring, 12-40.

Parasuraman, A. A. Zeithaml, V., and L. Berry, L. 1995. "A Conceptual Model of Service Quality and Its Implications for Future Research”. Journal of Marketing. Vol. 49 (fall)

Puspitawati. Lilis, dan Anggadini, Sri Dewi. 2011, "Sistem Informasi Akuntansi”, 1nd ed, Yogyakarta : Graha Ilmu, 
Richard L. Hughes, Robert C. Ginnett, and Gordon J. Curphy. 2012. Leadership, Enhancing the Lessons of Experience, Alih Bahasa: Putri Izzati. Jakarta: Salemba Humanika.

Robbins \& Judge. 2013. Organizational Behavior, Fifteenth Edition. Pearson Education, Inc

Santoso, Septiadi dan Oetomo, Hening Widi. 2013. Pengaruh Kualitas Pelayanan Terhadap Loyalitas Pelanggan Laboratorium Klinik Populer Surabaya. Jurnal Ilmu dan Riset Manajemen, Volume 2. Nomor 6. 2013: 1-20.

Saputra, Agus Tunggal. Bagia, I Wayan dan Yulianthini, Ni Nyoman. 2016. Pengaruh Kepuasan Kerja Dan Loyalitas Karyawan Terhadap Kinerja Karyawan. Jurnal Manajemen. Volume 4. 2016: 1-8.

Shandra, Metta Padyawati Kusuma dan Murwatiningsih. 2016. Kepuasan Konsumen Sebagai Mediasi Pengaruh Kualitas Pelayanan, Brand Image, dan Harga Terhadap Loyalitas Konsumen. Management Analysis Journal. Volume 5. Nomor 1. 2016: $36-43$.

Siswanto. 2010. Pengantar Manajemen.-cet.6. Bumi Aksara. Jakarta.

Soegandhi, Vannecia. M dkk. 2013. Pengaruh Kepuasan Kerja dan Loyalitas Kerja Terhadap Organizational Citizenship Behavior Pada Karyawan PT Surya Timur Sakti Jatim. Jurnal Manajemen, Volume 1. Nomor 1. Program Manajemen Bisnis, Program Studi Manajemen. Universitas Kristen Petra.

Tjiptono, Fandi, Chandra, 2007. Service, Quality\& Satisfaction, Edisi 2, Yogyakarta: Andi. Tjiptono, Fandi, dan Gregorius Chandra. 2012. Pemasaran Strategik. Andi. Yogyakarta Tjiptono, Fandy. 2014, Pemasaran Jasa - Prinsip, Penerapan, dan Penelitian, Andi Offset, Yogyakarta

Zakiy, Muhammad dan Azzahroh, Evrita Putri. 2017. Pengaruh Kualitas Layanan Terhadap Loyalitas Nasabah Bank Syariah Dengan Kepuasan Nasabah Sebagai Variabel Intevening. Jurnal Ekonomi dan Bisnis Islam. Volume 3. Nomor 1. 2017: 26-38. 